Brit. J. industr. Med., 1965, 22, 58.

\title{
ASSESSMENT OF MEAN RADIANT TEMPERATURE IN INDOOR ENVIRONMENTS
}

\author{
BY \\ BARBARA E. TREDRE \\ From the Division of Human Physiology, National Institute for Medical Research, London
}

(RECEIVED FOR PUBLICATION FEBRUARY 26, 1964)

\begin{abstract}
The mean radiant temperature (m.r.t.) is usually assessed as the radiation received at a point (or by a small sphere), but it is clearly important to know how adequately this parameter describes the heat load on a man, for in the presence of hot surfaces his shape and orientation may have significant effects. This paper presents the results of experiments designed to assess the radiant heat received by a man in a controlled temperature room in which non-uniform environments were achieved by locating a heated panel either overhead or on one wall. The m.r.t. was determined with reference to a point using $(a)$ the solid angle and temperature of each surface of the room, (b) a radiation thermopile, and $(c)$ a globe thermometer. The m.r.t. was also determined with reference to $(a)$ a cylinder 68 in. in height and 12 in. in diameter, and $(b)$ models of standing and sitting men. It seems that in indoor environments, where there is no intense radiation from sharply localized sources, the single estimation of m.r.t. with a globe thermometer at 45 in. above the floor will generally give a satisfactory indication of the heat load on a standing or sitting man.
\end{abstract}

The thermal environment of a room must be specified in terms of the air temperature and the mean radiant temperature if the air temperature differs from that of the surrounding surfaces. The radiant heat received from these surfaces is a function of their temperature and is expressed as the mean radiant temperature (m.r.t.). The m.r.t. may be defined as the uniform temperature at which black surrounding surfaces would have to be maintained to exchange the same amount of heat with the receiving body as the surrounding surfaces being considered (Barker, 1932). The m.r.t. at a point in a room will vary with the proximity of that point to the boundary surfaces radiating with high or low intensity, and it will be affected by the radiation received from occupants, furniture or equipment.

The m.r.t. has been used to denote the average temperature of the boundary surfaces of a room (British Standard Code of Practice, 1949; American Society of Heating and Ventilating Engineers, 1945). This temperature is a single figure for a given room at a particular time, and the true m.r.t. will only give some measure of agreement with it when the surfaces are of uniform temperature. In the calculation of average surface temperature the temperature of any surface is weighted by its area, but the in- fluence of the same surface on the m.r.t. is proportional to the solid angle it subtends at the observation point.

The m.r.t. is most conveniently assessed as the radiation received at a point or small sphere, but it is important to know how adequately this parameter describes the heat load on a man, for his shape and orientation towards the various radiating surfaces may have significant effects. Experiments were therefore undertaken to determine the m.r.t. with reference to $(a)$ a point and $(b)$ a non-spherical object such as the human body. Various methods of estimating m.r.t. were used and their results are compared.

\section{Experimental Arrangements}

The experiments were conducted in an air-conditioned cubicle $7 \mathrm{ft} .9$ in. $\times 7 \mathrm{ft} .6$ in. $\times 11 \mathrm{ft} .3$ in. in height (Fig. 1). Air was admitted through a perforated zinc grid extending over the whole ceiling and was drawn out at floor level through ducting on one wall. The temperature of the entering air was thermostatically controlled to within $0 \cdot 5^{\circ} \mathrm{F}$. $\left(0 \cdot 28^{\circ} \mathrm{C}\right.$.) and was maintained at $65^{\circ} \mathrm{F}$. $\left(18 \cdot 33^{\circ} \mathrm{C}\right.$.). The humidity was not controlled.

Non-uniform environments were achieved by locating a $6 \mathrm{ft}$. $\times 4 \mathrm{ft}$. electrically heated panel horizontally over- 


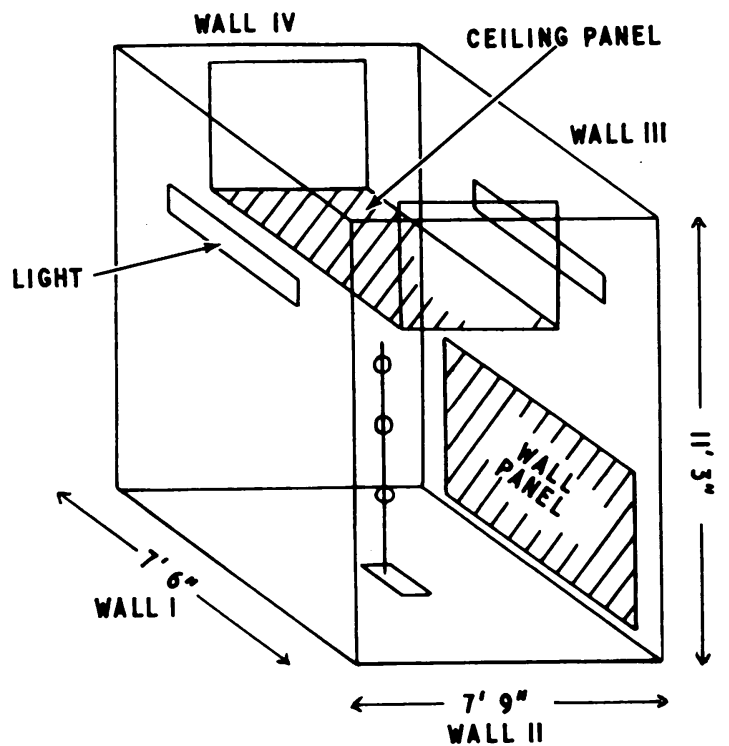

FIG. 1.-An isometric sketch of the cubicle showing the position of the heating panels and lights relative to the numbered walls. Three globe thermometers are shown in position at heights 64 , 45 , and 24 in. above the centre of the floor.

head or vertically on one wall. The ceiling panel could be raised or lowered and was lagged above with slag wool. When the panel (4 $\mathrm{ft}$. in height) was fixed to the centre of one wall 3 in. from the floor, it was replaced overhead by a false panel in order to keep the distribution of air constant.

A total of 71 thermojunctions were fixed to the walls, floor, ceiling, and heating panel. The walls were divided into equal areas (30 in. $\times 30$ in.) above an 18 in. strip at floor level, and a thermojunction soldered to a $\frac{3}{4}$ in. copper plate was fixed to the centre of each area. The floor was divided into nine equal areas, and one thermojunction was attached to the ceiling grid. The positions of nine junctions on the heating panel were chosen to give an average temperature agreeing with the average of measurements in 36 positions.

\section{Measurement and Calculation of Mean Radiant Temperature}

The radiant exchange within an enclosure with surfaces of high emissivity is practically the same as if all surfaces are thermally black owing to the rapid damping out of reflected energy. The emissivity of the surfaces in the cubicle does not therefore enter as a factor into any of the following methods of calculating the mean radiant temperature.

\section{With reference to a Point or Sphere}

Direct Measurement with a Radiation Thermopile.The mean intensity of radiation at a point 45 in. above the centre of the floor was measured directly with a Kipp thermopile used with a Cambridge potentiometer. The thermopile was fitted with a reflecting cone of $30^{\circ}$ angle and was clamped to a stand provided with horizontal and vertical scales. It was calculated that if the thermopile was to face every part of the sphere surrounding it, 46 readings were necessary for the determination of m.r.t. The method was that used by Bedford and Warner (1934).

Calculation from Solid Angles and Measurements of Surface Temperatures.-For all surface areas incorporating a thermojunction, solid angles were calculated with reference to points 24,45 , and 64 in. above the centre of the floor. These three sets of figures were calculated separately for the conditions when the heating panel was fixed (a) horizontally overhead at a height of $8 \mathrm{ft}$. from the floor, (b) similarly overhead at a height of $10 \mathrm{ft}$., and (c) on the wall. The method of calculation (Chrenko, 1953) was as follows. If a line OP is drawn from the point of reference $O$ such that it meets any one surface area $A B C D$ at right angles and $A B C D$ is divided into four rectangles at $\mathbf{P}$, the total solid angle in steradians at $\mathrm{O}$ is given by

$\Omega=\tan ^{-1} \frac{a c}{z p_{1}}+\tan ^{-1} \frac{b c}{z p_{2}}+\tan ^{-1} \frac{b d}{z p_{3}}+\tan ^{-1} \frac{a d}{z p_{3}}$

where distances $a, z, p$, etc., are those indicated in Figure 2.

If the temperatures of the surface areas in the cubicle are $T_{1}, T_{2}, T_{3}$, etc., ( ${ }^{\circ} \mathrm{F}$.Abs.) and the corresponding solid angles subtended at 0 are $x_{1}, x_{2}, x_{3}$, etc. ( $\%$ of $4 \pi$ steradians), the m.r.t. ( ${ }^{\circ} \mathrm{F}$.Abs.) is given by

$$
T_{W}{ }^{4}=\frac{x_{1} T_{1}^{4}}{100}+\frac{x_{2} T_{2}^{4}}{100}+\frac{x_{3} T_{3}^{4}}{100} \text { etc. }
$$

The mean radiant temperature $\left({ }^{\circ} \mathrm{F}\right.$.) was calculated with reference to points at the three heights from the floor.

Calculation from Measurements made with a Globe Thermometer.-Observations were made with three 6-in. globe thermometers placed at heights 24,45 , and 64 in. above the centre of the floor. Each blackened copper

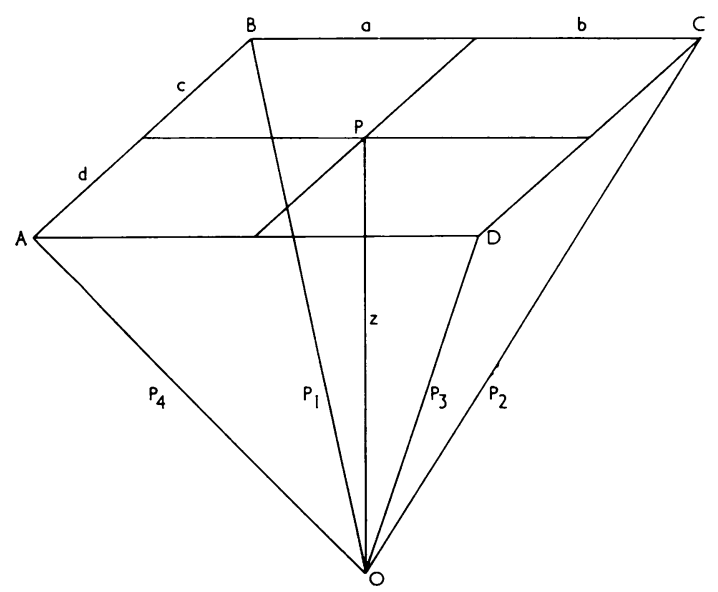

FIG. 2.-Diagram to illustrate the calculation of the solid angle subtended by area $A B C D$ at a point $O$. 
globe contained a thermocouple at its centre. Thermocouple measurements of air temperature were taken simultaneously at these heights. Air speeds were measured in each position with a hot wire anemometer (Vernon and Manley, 1926). They varied between 18 and $45 \mathrm{ft}$. $/ \mathrm{min}$.

From the globe temperature $\left(t_{g}{ }^{\circ} \mathrm{F}\right.$. or $T_{G}{ }^{\circ} \mathrm{F}$.Abs. $)$, the air temperature $\left(t_{a}\right)$, and the air speed $(v \mathrm{ft} . / \mathrm{min}$.$) , the$ m.r.t. $\left(T_{W}{ }^{\circ}\right.$ F.Abs. $)$, at each height was calculated using the formula of Bedford and Warner (1934):

$$
\left.T_{W^{4}} \times 10^{-9}=T_{G^{4}} \times 10^{-9}+0.0128 \sqrt{v\left(t_{g}\right.}-t_{a}\right)
$$

\section{With reference to the Human Body}

Measurements using Metal Models of Men.-The metal models used in the present experiments have been previously described by Newling (1954) and Macpherson (1960). Two of the models were roughly comparable in size and shape to a standing man and the other two to a sitting man. The two models (Fig. 3) were identical except that one was painted matt black whereas the other was highly polished. The models were electrically heated and each had two internal fans to ensure that there were no wide differences in temperature over the surface. Surface temperatures were measured with 15 thermojunctions soldered to representative points on the inner surface.

The black and polished models were used separately to prevent radiation exchange between them. The polished model was placed in the centre of the cubicle and its

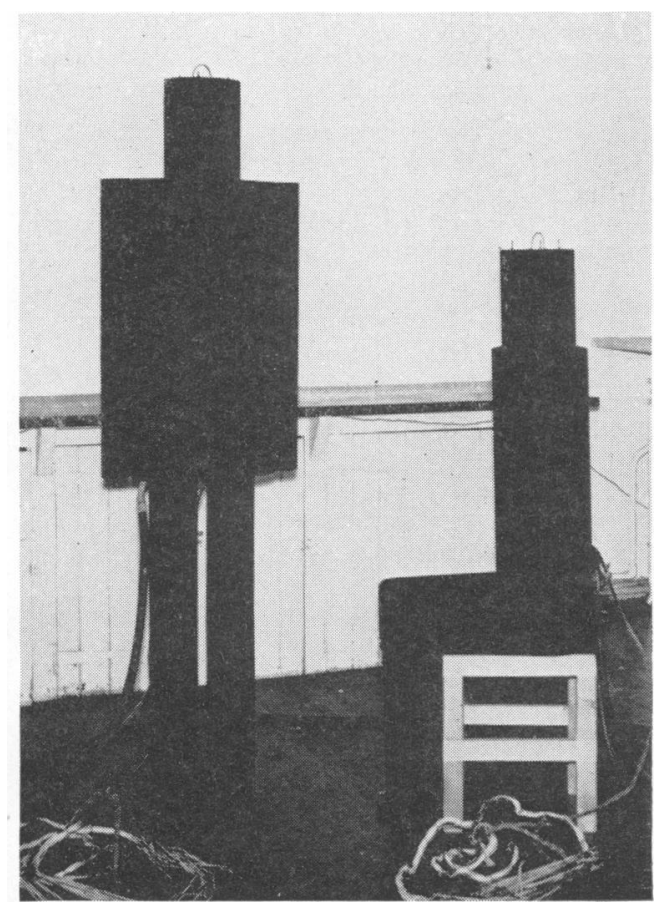

FIG. 3.-The black metal models of standing and sitting men. power supply was adjusted until its mean surface temperature reached equilibrium at $80^{\circ} \mathrm{F}$. The polished model was then replaced by the black model, and again the power required to give a mean surface temperature of $80^{\circ} \mathrm{F}$. at equilibrium was ascertained.

Since the surface temperature of the models was higher than the mean radiant temperature the power required by the black model was greater than that required by the polished one. The difference in power requirements was a measure of the heat lost to the environment by radiation, since the heat lost by convection and conduction was the same for each model.

The mean radiant temperature was calculated from the following equation:

$$
T_{W^{4}}=T_{M}^{4}-\frac{\Delta W}{\sigma A\left(E_{B}-E_{P}\right)}
$$

where $\sigma=$ Stefan's constant or $5.735 \times 10^{-12} ; E_{B}$ and $E_{P}=$ the emissivities of the black and polished models respectively; $A=$ the radiating surface area of the models; $T_{M}=$ the mean surface temperature of the models, in ${ }^{\circ} \mathrm{F}$.Abs.; $T_{W}=$ the mean radiant temperature, in ${ }^{\circ} \mathrm{F}$.Abs.; $\Delta W=$ the difference in power supply to the models, in watts.

The effective radiating areas of the standing and sitting models and the emissivities of all four models were determined by experiment. They were:

$$
\begin{aligned}
\text { Standing models } A & =1.525 \times 10^{4} \mathrm{~cm}^{2} \\
E_{B} & =0.96 \quad E_{P}=0.20 \\
\text { Sitting models } \quad A & =1.238 \times 10^{4} \mathrm{~cm}^{2} \\
E_{B} & =0.97 \quad E_{P}=0.15
\end{aligned}
$$

Calculations from Shape Factors and Measurements of Surface Temperatures.-A shape factor is dependent on the size and geometrical arrangement of two surfaces which are exchanging energy. Raber and Hutchinson (1947) defined the shape factor in the form of a double integral but stated that when the complex form of the human body is considered, evaluation of the integral becomes impossible. They therefore determined experimentally the shape factors of the various surfaces of a room with respect to a man standing in any one position. They used a clothed dummy to represent an average man $5 \mathrm{ft} .10 \mathrm{in}$. tall and weighing $165 \mathrm{lb}$., and their results were verified on human subjects of varying build. Each surface of the room was divided into small areas (1 sq. $\mathrm{ft}$.), and a mechanical integrator was placed over the centre of each area in turn. A beam of light was directed from the instrument over the outline of the dummy. The measured area of the closed curve so drawn represented the shape factor of the dummy with respect to the small area. Raber and Hutchinson (1947) and Hutchinson and Baker (1951) provided graphs and tables from which these shape factors can be read. The overall shape factor for any one main surface such as a wall can be obtained by taking an average of the shape factors for the small areas enclosed within that surface. When the shape factors for each main surface are multiplied by their areas, the sum of the products should be 19.5 , i.e., the effective radiating area of the clothed dummy (sq. ft.). Each product is divided 
by 19.5 to obtain the final shape factor for each main surface.

The Raber and Hutchinson data were used to determine the shape factors of surface areas with respect to their average man standing in the centre of the cubicle under the $8 \mathrm{ft}$. or $10 \mathrm{ft}$. ceiling panel and facing a particular wall. The areas of the portion of the various surfaces, the temperatures of which were represented by the individual thermocouples, were too small for their shape factors to be estimated accurately. For that reason the shape factors for each wall, the floor, the ceiling, and the heated panel were ascertained, and the average temperature of each of these surfaces was calculated by weighting each individual temperature according to the area it represented. The mean radiant temperature was calculated from the sum of the products of these weighted mean surface temperatures and the shape factors of the various surfaces.

Calculation with reference to a Cylinder of Height (68 in.) and Radiation Surface Area (18.6 sq. ft. $\left(1 \cdot 73 \mathrm{m.}^{2}\right)$ ) comparable with that of a Man.-Dufton and Marley (1942) constructed a diagram which portrayed the various surfaces of a room such that each area of the diagram afforded a measure of the effect of the corresponding surface on a eupatheoscope. Their equations were adapted for a cylinder $68 \mathrm{in}$. high and $12 \mathrm{in.}$ in diameter standing on the floor in the centre of the cubicle, and a similar projection diagram was constructed showing the various surfaces of the cubicle (Fig. 4). All vertical boundaries within the $90^{\circ}$ of azimuth to the left and right of the cylinder were drawn to scale as vertical lines. As the angles of altitude from the cylinder decreased with increasing angles of azimuth, all horizontal boundaries were drawn as altitude curves at calculated distances above and below the horizontal plane through the centre of the cylinder. All the areas (Fig. 4) were measured with a planimeter and these 'solid angles' were inserted in equation 2 (p. 59) to obtain the mean radiant temperature with respect to the cylinder.

Calculation from Observations with Globe Thermometers Placed at Different Heights.-Newling (1954) found that the average of the mean radiant temperatures calculated from three globe thermometers at heights 24 , 45 , and 66 in. from the floor agreed very closely with the mean radiant temperature derived from observations with the metal models of men. In this investigation similar comparisons were made.

\section{Experimental Procedure}

One experiment on the standing models was performed each day at one of two ceiling heights ( $8 \mathrm{ft}$. or $10 \mathrm{ft}$.) or with the panel on the wall and at one of five panel temperatures (unheated, $26 \cdot 7^{\circ} \mathrm{C}$., $35 \cdot 0^{\circ} \mathrm{C}$., $43 \cdot 3^{\circ} \mathrm{C}$., and $48 \cdot 9^{\circ} \mathrm{C}$.). Experiments on the sitting models were confined to three panel temperatures (unheated, $35.0^{\circ} \mathrm{C}$., and $48.9^{\circ} \mathrm{C}$.). As any one experiment with the metal models took more than three hours to complete, other estimations of m.r.t. were made before and after that with the models. The m.r.t's obtained by any one method were

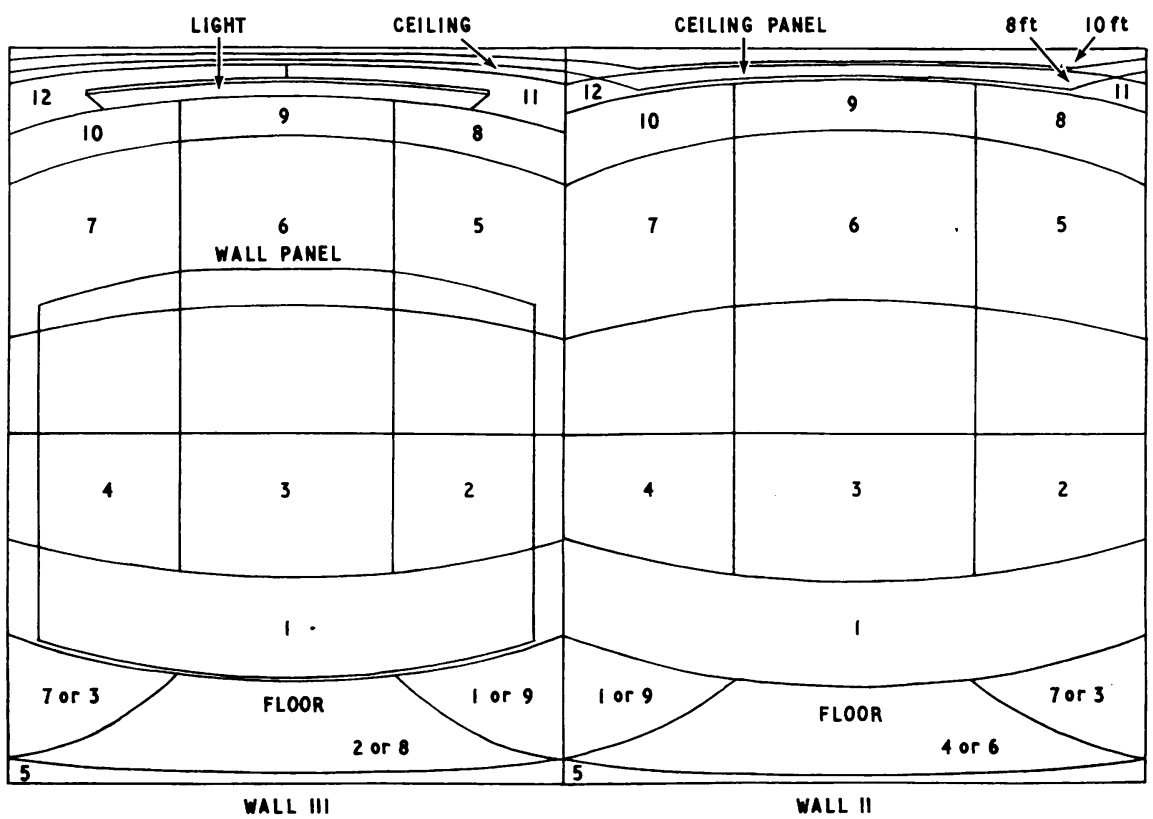

FIG. 4.-The projection of the sectional surface areas, heating panels, and lights at a cylinder (height 68 in. and diameter 12 in.) standing on the floor in the centre of the cubicle. Numbered areas refer to thermocouple positions. Walls I and IV are identical with walls III and II. 
then averaged in order that a comparison could be made with the m.r.t's obtained from the metal models.

The maximum increase in panel temperature over the day was $1.05^{\circ} \mathrm{C}$. and that of the m.r.t. $0.78^{\circ} \mathrm{C}$., whatever the panel position and temperature and however the m.r.t. was measured. Prevailing external weather conditions did affect the temperature of the inner surfaces of the walls so that it will be apparent in Tables 1 and 2 that in groups of experiments at similar panel temperatures the m.r.t's obtained by any one method do not necessarily agree.

The Fahrenheit scale was used throughout the investigation and all the results were expressed to the nearest $0 \cdot 1^{\circ} \mathrm{F}$. The figures have been converted to the Centigrade scale for this paper and are therefore expressed to the nearest $0.01{ }^{\circ} \mathrm{C}$.

\section{Results}

When the panel was unheated, i.e., when its temperature was about $20^{\circ} \mathrm{C}$. and the surface temperatures were fairly uniform, all the methods used to estimate the m.r.t. gave very similar results (see Tables 1 and 2).

The results in Table 1 and Fig. 5 show that errors will arise in assuming that the average surface temperature is equivalent to the m.r.t. The error was negligible when the panel was unheated and the surroundings were at uniform temperature. When the panel was at a height of $8 \mathrm{ft}$. from the floor and at a temperature of $50^{\circ} \mathrm{C}$. the average surface temperature was as much as $3^{\circ} \mathrm{C}$. higher than the m.r.t. measured directly with the thermopile at 45 in. from the floor.

Mean Radiant Temperature at a Point.-The solid angles $(\% 4 \pi)$ formed by the panel at 24,45 , and 64 in. above the centre of the floor were $4.52,7.92$, and $14 \cdot 83$ with the ceiling panel at $8 \mathrm{ft}$., $2 \cdot 71,4 \cdot 21$, and 6.76 with the ceiling panel at $10 \mathrm{ft}$., and 9.86 , 8.63 , and 5.82 with the panel on the wall. The wall panel had therefore a greater effect on the m.r.t. at 24 in. and 45 in. above the floor than had either of the ceiling panels. The ceiling panels had the greater effect on the m.r.t. at 64 in.

The lower the ceiling panel and the higher its temperature, the greater was the vertical gradient in m.r.t. over the height of a standing man. With the ceiling panel at $8 \mathrm{ft}$. and at a temperature of $50.05^{\circ} \mathrm{C}$., the m.r.t. at 64 in. was $3.55^{\circ} \mathrm{C}$. higher than that at 24 in. A positive gradient of $0.22^{\circ} \mathrm{C}$. was present when the panel was unheated. With the heated panel on the wall the variation in m.r.t. was less than with the panel overhead, and the gradient was negative. The m.r.t. at 64 in. was $1 \cdot 22^{\circ} \mathrm{C}$. lower than that at 24 in. when the wall panel was at a temperature of $51 \cdot 55^{\circ} \mathrm{C}$.

The m.r.t. referred to a point can be estimated from surface temperatures and solid angles with a very satisfactory degree of accuracy, for the values

TABLE 1

COMPARISON OF ESTIMATES OF MEAN RADIANT TEMPERATURE FROM STANDING METAL MODELS OF MEN WITH THOSE OBTAINED FROM THE VARIOUS OTHER METHODS

\begin{tabular}{|c|c|c|c|c|c|c|c|c|c|c|c|}
\hline \multirow[b]{2}{*}{$\begin{array}{l}\text { Position of } \\
\text { Heating } \\
\text { Panel }\end{array}$} & \multirow[b]{2}{*}{$\begin{array}{l}\text { Panel } \\
\text { Temp. } \\
\left({ }^{\circ} \mathrm{C} .\right)\end{array}$} & \multirow[b]{2}{*}{$\begin{array}{c}\text { Number } \\
\text { of } \\
\text { Expts }\end{array}$} & \multirow[b]{2}{*}{$\begin{array}{l}\text { Average } \\
\text { Surface } \\
\text { Temp. } \\
\left({ }^{\circ} \mathrm{C} .\right) \text { of } \\
\text { Cubicle }\end{array}$} & \multicolumn{8}{|c|}{ Mean Value of Mean Radiant Temperature $\left({ }^{\circ} \mathrm{C}.\right)$ as estimated from } \\
\hline & & & & $\begin{array}{l}\text { Metal } \\
\text { Models } \\
\text { of Men }\end{array}$ & $\begin{array}{c}\text { Raber and } \\
\text { Hutchin- } \\
\text { son Shape } \\
\text { Factor } \\
\text { Data for a } \\
\text { Standing } \\
\text { Man }\end{array}$ & $\begin{array}{c}\text { Average } \\
\text { from three } \\
\text { Globe } \\
\text { Therm. at } \\
\text { Heights } \\
24,45 \text {, and } \\
64 \text { in. }\end{array}$ & $\begin{array}{c}\text { Globe } \\
\text { Therm. at } \\
\text { Height } \\
45 \text { in. }\end{array}$ & $\begin{array}{c}\text { Average of } \\
\text { three esti- } \\
\text { mates from } \\
\text { Surface } \\
\text { Temps. } \\
\text { ref. to } \\
\text { Points 24, } \\
45 \text {, and } \\
64 \text { in. from } \\
\text { Floor }\end{array}$ & $\begin{array}{l}\text { Surface } \\
\text { Temps. } \\
\text { with ref. } \\
\text { to Point } \\
45 \text { in. } \\
\text { from } \\
\text { Floor }\end{array}$ & $\begin{array}{l}\text { Projection } \\
\text { referred to } \\
\text { Cylinder } \\
68 \text { in. high }\end{array}$ & $\begin{array}{l}\text { Radiation } \\
\text { Thermo-- } \\
\text { pile with } \\
\text { ref. to } \\
\text { Point } \\
45 \text { in. } \\
\text { from } \\
\text { Floor }\end{array}$ \\
\hline $\begin{array}{l}\text { Ceiling at } \\
\text { height of } \\
8 \mathrm{ft} \text {. }\end{array}$ & $\begin{array}{l}19 \cdot 83 \\
26.83 \\
35.61 \\
42.94 \\
50.00\end{array}$ & $\begin{array}{l}4 \\
5 \\
5 \\
4 \\
4\end{array}$ & $\begin{array}{l}20.17 \\
21.94 \\
24.00 \\
25.72 \\
27.28\end{array}$ & $\begin{array}{l}20 \cdot 28 \\
21 \cdot 39 \\
22 \cdot 44 \\
23 \cdot 33 \\
23 \cdot 83\end{array}$ & $\begin{array}{l}20 \cdot 28 \\
21 \cdot 33 \\
22 \cdot 22 \\
23 \cdot 06 \\
23 \cdot 67\end{array}$ & $\begin{array}{l}20 \cdot 11 \\
21 \cdot 28 \\
22 \cdot 33 \\
23 \cdot 22 \\
23 \cdot 83\end{array}$ & $\begin{array}{l}20 \cdot 06 \\
21 \cdot 17 \\
22 \cdot 17 \\
23 \cdot 00 \\
23 \cdot 50\end{array}$ & $\begin{array}{l}20 \cdot 17 \\
21 \cdot 50 \\
22 \cdot 78 \\
23.94 \\
24 \cdot 89\end{array}$ & $\begin{array}{l}20 \cdot 17 \\
21 \cdot 39 \\
22 \cdot 61 \\
23 \cdot 67 \\
24 \cdot 50\end{array}$ & $\begin{array}{l}20.11 \\
21.06 \\
21.83 \\
22.50 \\
22.94\end{array}$ & $\begin{array}{l}20 \cdot 39 \\
21 \cdot 61 \\
22 \cdot 72 \\
23 \cdot 61 \\
24 \cdot 28\end{array}$ \\
\hline $\begin{array}{l}\text { Ceiling at } \\
\text { height of } \\
10 \mathrm{ft} \text {. }\end{array}$ & $\begin{array}{l}20 \cdot 11 \\
26 \cdot 78 \\
34 \cdot 72 \\
41 \cdot 94 \\
48 \cdot 72\end{array}$ & $\begin{array}{l}4 \\
4 \\
4 \\
4 \\
5\end{array}$ & $\begin{array}{l}20 \cdot 50 \\
21 \cdot 39 \\
22 \cdot 28 \\
23 \cdot 39 \\
24 \cdot 11\end{array}$ & $\begin{array}{l}20 \cdot 78 \\
21 \cdot 39 \\
21 \cdot 89 \\
22 \cdot 67 \\
22 \cdot 83\end{array}$ & $\begin{array}{l}20 \cdot 56 \\
21 \cdot 17 \\
21 \cdot 61 \\
22 \cdot 33 \\
22 \cdot 61\end{array}$ & $\begin{array}{l}20 \cdot 39 \\
21 \cdot 11 \\
21 \cdot 61 \\
22 \cdot 50 \\
22.89\end{array}$ & $\begin{array}{l}20 \cdot 39 \\
21 \cdot 17 \\
21.61 \\
22.39 \\
22.78\end{array}$ & $\begin{array}{l}20.56 \\
21.33 \\
21.94 \\
22.94 \\
23.39\end{array}$ & $\begin{array}{l}20 \cdot 50 \\
21 \cdot 28 \\
21 \cdot 89 \\
22 \cdot 83 \\
23 \cdot 28\end{array}$ & $\begin{array}{l}20 \cdot 50 \\
21.06 \\
22.00 \\
22.17 \\
22 \cdot 39\end{array}$ & $\begin{array}{l}20 \cdot 67 \\
21 \cdot 56 \\
22.11 \\
23.06 \\
23 \cdot 39\end{array}$ \\
\hline $\begin{array}{l}\text { Wall (false } \\
\text { ceiling at } \\
\text { height of } \\
8 \mathrm{ft} \text {.) }\end{array}$ & $\begin{array}{r}20.22 \\
27.00 \\
34.72 \\
* 34.83 \\
43.55 \\
51.66 \\
* 51.44\end{array}$ & $\begin{array}{l}5 \\
5 \\
6 \\
5 \\
6 \\
5 \\
3\end{array}$ & $\begin{array}{l}20 \cdot 56 \\
21 \cdot 33 \\
22 \cdot 17 \\
21 \cdot 67 \\
23 \cdot 33 \\
24 \cdot 44 \\
23 \cdot 94\end{array}$ & $\begin{array}{l}20 \cdot 28 \\
21 \cdot 22 \\
22 \cdot 22 \\
22 \cdot 00 \\
23 \cdot 44 \\
24 \cdot 67 \\
25 \cdot 00\end{array}$ & $\begin{array}{l}20 \cdot 67 \\
21 \cdot 56 \\
22 \cdot 50 \\
22 \cdot 78 \\
23 \cdot 72 \\
24 \cdot 38 \\
26 \cdot 56\end{array}$ & $\begin{array}{c}20 \cdot 33 \\
21 \cdot 28 \\
22 \cdot 17 \\
-\overline{2} \\
23 \cdot 33 \\
24 \cdot 50 \\
-\end{array}$ & $\begin{array}{l}20 \cdot 28 \\
21 \cdot 39 \\
22 \cdot 28 \\
21 \cdot 78 \\
23 \cdot 44 \\
24 \cdot 61 \\
24 \cdot 17\end{array}$ & $\begin{array}{l}20 \cdot 61 \\
21.61 \\
22.61 \\
22.06 \\
24.00 \\
25.39 \\
24.89\end{array}$ & $\begin{array}{l}20 \cdot 61 \\
21 \cdot 61 \\
22 \cdot 72 \\
22 \cdot 11 \\
24 \cdot 11 \\
25.56 \\
25 \cdot 06\end{array}$ & $\begin{array}{l}20 \cdot 56 \\
21 \cdot 78 \\
23 \cdot 11 \\
22 \cdot 56 \\
24 \cdot 78 \\
26 \cdot 50 \\
26 \cdot 00\end{array}$ & $\begin{array}{l}20 \cdot 72 \\
21 \cdot 78 \\
22 \cdot 72 \\
22 \cdot 17 \\
24 \cdot 06 \\
25 \cdot 22 \\
24 \cdot 78\end{array}$ \\
\hline
\end{tabular}

* Metal models full face to the wall panel and globe thermometer at 64 in. not in position. In all other experiments metal models facing along the length of the ceiling panel or profile to the wall panel. 
agreed very closely with those obtained by direct measurement with the thermopile even when the panel temperature was as high as $51.7^{\circ} \mathrm{C}$. The average m.r.t. of 377 measurements taken with the thermopile at $45 \mathrm{in}$. above the floor was $22 \cdot 72^{\circ} \mathrm{C}$. with a standard deviation of $\pm 2 \cdot 11^{\circ} \mathrm{C}$, and the average m.r.t. referred to the same point calculated from surface temperatures and solid angles was $22.72 \pm 1.89^{\circ} \mathrm{C}$. The average difference between pairs of observations was $0 \cdot 18^{\circ} \mathrm{C}$. and the root-mean square deviation was $0.23^{\circ} \mathrm{C}$. In no pair was the difference greater than $0.67^{\circ} \mathrm{C}$. and in only 38 pairs was it greater than $0.28^{\circ} \mathrm{C}$.

The average m.r.t. of the 377 observations made with the globe thermometer at 45 in. above the floor was $22.28 \pm 2 \cdot 11^{\circ} \mathrm{C}$. The difference between the average m.r.t. referred to the thermopile and that referred to the globe was $0.44^{\circ} \mathrm{C}$. In only 28 of the 377 observations was the globe result greater than that from the thermopile. In the group averages given in Table 1, the m.r.t. estimated from surface temperatures did not differ from that measured by the thermopile by more than $\pm 0 \cdot 34^{\circ} \mathrm{C}$. but that measured by the globe was always less than that measured by the thermopile, the error increasing to as much as $0.78^{\circ} \mathrm{C}$. at the higher panel temperatures.

Mean Radiant Temperature as it Affects a Standing Man (see Table 1 and Fig. 5).-With the panel overhead there was close agreement between the results obtained $(a)$ from the standing metal models of men, and $(b)$ with reference to a standing man calculated from surface temperatures and shape factors based on the Raber and Hutchinson data. When the men were standing profile to the panel on the wall the results agreed to within $0.39^{\circ} \mathrm{C}$. Differences between the m.r.t's obtained from the metal models and the thermopile show that the m.r.t. from the models increased as the models were turned from the profile position to face the wall panel.

The averages of the values of the m.r.t's obtained from three globe thermometers at heights 24,45 , and $64 \mathrm{in}$. above the floor agreed very closely with the m.r.t's calculated from the standing metal men. In the heated wall panel experiments the results from the three globes were lower than those from the 45 in.

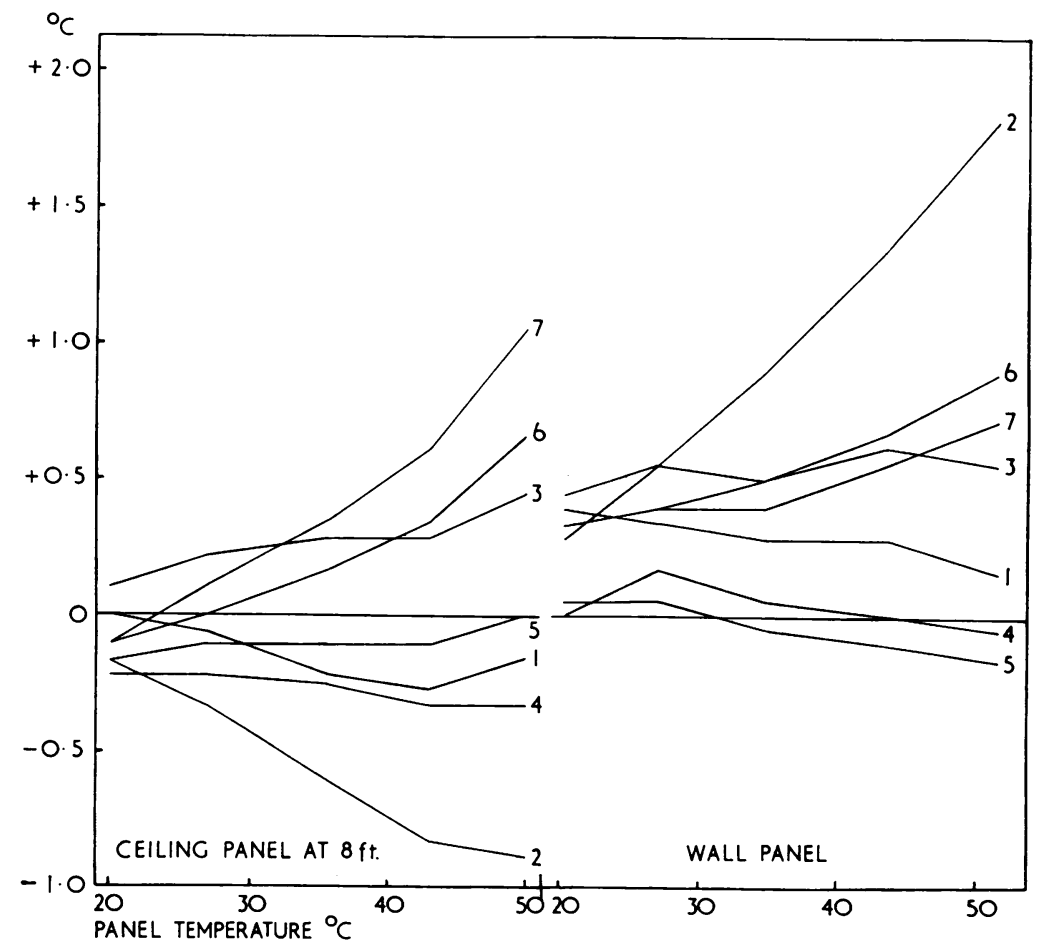

FIG. 5.-Deviation of the various estimates of mean radiant temperature from those obtained from the standing metal models of men. M.R.T. from (1) Raber and Hutchinson data; (2) cylinder; (3) thermopile at 45 in.; (4) globe thermometer at 45 in.; (5) three globe thermometers; (6) surface temperature referred to point at 45 in.; (7) surface temperature referred to three points; - MINUS M.R.T. 
globe, so that although in eight experiments the 64 in. globe was not in position and the results from the three globes were not obtained, it can be said that the 45 in. globe gave the better comparison with the models whether the models were full face or profile to the panel.

Agreement between the m.r.t's obtained from the metal models of standing men and the average m.r.t's obtained from surface temperatures with reference to three points at 24,45 , and 64 in. above the floor was not good. When the panel was heated, the m.r.t's obtained from surface temperatures were higher than those from the models, the error increasing with the panel temperature. With the $8 \mathrm{ft}$. ceiling panel at $50^{\circ} \mathrm{C}$. the error was $1.06^{\circ} \mathrm{C}$. The m.r.t's derived from surface temperatures and solid angles giving the closest agreement with the results from the models were those referred to (1) 45 in. or the mean of 24 and $45 \mathrm{in}$. with the panel overhead, (2) 64 in. with the models' profile to the wall panel, and (3) $45 \mathrm{in}$. or the mean of 45 and $64 \mathrm{in}$. with the models' full face to the wall panel. All these results have not been tabulated since their agreement was no better than that between the three globes or the 45 in. globe and the standing models.

In the experiments with the heated panel overhead, the m.r.t. calculated with reference to the cylinder was always lower than that obtained by any of the other methods. With the heated panel on the wall, it was always higher. At a panel temperature of $51.66^{\circ} \mathrm{C}$., the difference between the m.r.t's referred to the cylinder and the standing models was as much as $1.83^{\circ} \mathrm{C}$.

Finally, the results given in Table 1 show that as the temperature of the overhead panel increased above $26 \cdot 7^{\circ} \mathrm{C}$., the m.r.t. measured directly by the thermopile at 45 in. above the floor became progressively higher than that obtained from the metal models of standing men. The m.r.t. at 45 in. was $0.45^{\circ} \mathrm{C}$. higher than that from the models when the ceiling panel was at a height of $8 \mathrm{ft}$. and at a temperature of $50^{\circ} \mathrm{C}$. With the wall panel at a temperature of about $51.7^{\circ} \mathrm{C}$., the m.r.t. at 45 in. was $0.55^{\circ} \mathrm{C}$. higher or $0.12^{\circ} \mathrm{C}$. lower than the m.r.t. from the standing models according as the models were profile or full-face to the panel.

Mean Radiant Temperature as it Affects a Sitting Man.-A comparison may be made between the m.r.t's obtained from the standing and sitting models of men if these m.r.t's are subtracted from the 'standard' thermopile results in Tables 1 and 2. Table 3 summarizes these differences in the experiments at panel temperatures between 48.72 and $51 \cdot 66^{\circ} \mathrm{C}$. The m.r.t's obtained from the standing models were higher or lower than those from the sitting models when the panel was overhead at $8 \mathrm{ft}$. or on the wall respectively. The results from the sitting models facing the wall panel were in turn

TABLE 2

COMPARISON OF ESTIMATES OF MEAN RADIANT TEMPERATURE FROM SITTING METAL MODELS OF MEN WITH THOSE OBTAINED FROM THE VARIOUS OTHER METHODS

\begin{tabular}{|c|c|c|c|c|c|c|c|c|c|c|c|}
\hline \multirow{3}{*}{$\begin{array}{c}\text { Position } \\
\text { of Heating } \\
\text { Panel }\end{array}$} & \multirow{3}{*}{$\begin{array}{l}\text { Panel } \\
\text { Temp. } \\
\left({ }^{\circ} \mathrm{C} .\right)\end{array}$} & \multirow{3}{*}{$\begin{array}{c}\text { Number } \\
\text { of } \\
\text { Expts }\end{array}$} & \multicolumn{9}{|c|}{ Mean Value of Mean Radiant Temperature $\left({ }^{\circ} \mathrm{C}.\right)$ as estimated from } \\
\hline & & & \multirow{2}{*}{$\begin{array}{l}\text { Metal } \\
\text { Models } \\
\text { of Men }\end{array}$} & \multirow{2}{*}{\begin{tabular}{|c|} 
Average \\
from \\
Three \\
Globe \\
Therm. at \\
Heights \\
24,45 , and \\
64 in.
\end{tabular}} & \multirow{2}{*}{$\begin{array}{c}\text { Average } \\
\text { from } \\
\text { Two } \\
\text { Globe } \\
\text { Therm. at } \\
\text { Heights } \\
24 \text { and } \\
45 \text { in. }\end{array}$} & \multicolumn{2}{|c|}{$\begin{array}{c}\text { Globe Thermometer } \\
\text { at Heights: }\end{array}$} & \multicolumn{3}{|c|}{$\begin{array}{l}\text { Surface Temperatures with } \\
\text { reference to Points from } \\
\text { Floor: }\end{array}$} & \multirow{2}{*}{$\begin{array}{l}\text { Radiation } \\
\text { Thermo- } \\
\text { pile with } \\
\text { ref. to } \\
\text { a Point } \\
45 \text { in. } \\
\text { from } \\
\text { Floor }\end{array}$} \\
\hline & & & & & & 24 in. & 45 in. & $24 \mathrm{in.}$ & 45 in. & $64 \mathrm{in.}$ & \\
\hline $\begin{array}{l}\text { Ceiling at } \\
\text { height of } \\
8 \mathrm{ft} .\end{array}$ & $\begin{array}{l}19 \cdot 89 \\
19 \cdot 44 \\
35 \cdot 22 \\
50 \cdot 16 \\
50 \cdot 22\end{array}$ & $\begin{array}{l}3 \\
1 \\
4 \\
3 \\
1\end{array}$ & $\begin{array}{l}20 \cdot 22 \\
19 \cdot 83 \\
22 \cdot 17 \\
23 \cdot 22 \\
23 \cdot 83\end{array}$ & $\begin{array}{c}20 \cdot 11 \\
22 \cdot 33 \\
24 \cdot 11 \\
-\end{array}$ & $\begin{array}{l}20 \cdot 00 \\
19 \cdot 39 \\
21 \cdot 89 \\
23 \cdot 17 \\
23 \cdot 67\end{array}$ & $\begin{array}{l}19 \cdot 89 \\
19 \cdot 28 \\
21 \cdot 61 \\
22 \cdot 67 \\
23 \cdot 17\end{array}$ & $\begin{array}{l}20 \cdot 06 \\
19 \cdot 56 \\
22 \cdot 17 \\
23 \cdot 72 \\
24 \cdot 22\end{array}$ & $\begin{array}{l}20 \cdot 00 \\
19 \cdot 28 \\
21 \cdot 94 \\
23 \cdot 17 \\
23 \cdot 78\end{array}$ & $\begin{array}{l}20 \cdot 17 \\
19.44 \\
22.61 \\
24.61 \\
25.06\end{array}$ & $\begin{array}{l}20 \cdot 28 \\
19 \cdot 61 \\
23 \cdot 83 \\
26 \cdot 94 \\
27 \cdot 33\end{array}$ & $\begin{array}{l}20 \cdot 39 \\
19 \cdot 67 \\
22 \cdot 67 \\
24 \cdot 39 \\
24 \cdot 67\end{array}$ \\
\hline $\begin{array}{l}\text { Ceiling at } \\
\text { height of } \\
10 \mathrm{ft} .\end{array}$ & $\begin{array}{l}35 \cdot 33 \\
34 \cdot 77 \\
49 \cdot 50 \\
49 \cdot 44\end{array}$ & $\begin{array}{l}2 \\
1 \\
1 \\
2\end{array}$ & $\begin{array}{l}22 \cdot 50 \\
21 \cdot 22 \\
23 \cdot 44 \\
22 \cdot 83\end{array}$ & $\begin{array}{c}22 \cdot 61 \\
23 \cdot 50 \\
-\end{array}$ & $\begin{array}{l}22 \cdot 39 \\
21 \cdot 44 \\
23 \cdot 11 \\
22 \cdot 78\end{array}$ & $\begin{array}{l}22 \cdot 28 \\
21 \cdot 17 \\
22 \cdot 83 \\
22 \cdot 39\end{array}$ & $\begin{array}{l}22 \cdot 56 \\
21 \cdot 67 \\
23 \cdot 33 \\
23 \cdot 17\end{array}$ & $\begin{array}{l}22 \cdot 83 \\
21 \cdot 33 \\
23 \cdot 61 \\
22 \cdot 89\end{array}$ & $\begin{array}{l}23 \cdot 06 \\
21 \cdot 67 \\
24 \cdot 22 \\
23 \cdot 50\end{array}$ & $\begin{array}{l}23 \cdot 50 \\
22 \cdot 17 \\
25 \cdot 11 \\
24 \cdot 44\end{array}$ & $\begin{array}{l}22.94 \\
21.67 \\
24.06 \\
23.39\end{array}$ \\
\hline $\begin{array}{l}\text { Wall (false } \\
\text { ceiling at } \\
\text { height of } 8 \mathrm{ft} \text {.) }\end{array}$ & $\begin{array}{l}19 \cdot 56 \\
35 \cdot 66 \\
51 \cdot 27\end{array}$ & $\begin{array}{l}5 \\
7 \\
5\end{array}$ & $\begin{array}{l}19 \cdot 78 \\
22 \cdot 50 \\
24 \cdot 72\end{array}$ & $\begin{array}{l}19 \cdot 89 \\
22 \cdot 33 \\
24 \cdot 56\end{array}$ & $\begin{array}{l}19 \cdot 83 \\
22 \cdot 39 \\
24 \cdot 72\end{array}$ & $\begin{array}{l}19 \cdot 83 \\
22 \cdot 50 \\
24 \cdot 94\end{array}$ & $\begin{array}{l}19 \cdot 89 \\
22 \cdot 28 \\
24 \cdot 56\end{array}$ & $\begin{array}{l}19 \cdot 89 \\
23 \cdot 00 \\
25 \cdot 56\end{array}$ & $\begin{array}{l}20 \cdot 00 \\
22 \cdot 78 \\
25 \cdot 22\end{array}$ & $\begin{array}{l}20 \cdot 00 \\
22 \cdot 39 \\
24 \cdot 33\end{array}$ & $\begin{array}{l}20 \cdot 17 \\
22 \cdot 78 \\
24 \cdot 94\end{array}$ \\
\hline $\begin{array}{l}\text { Wall (false } \\
\text { ceiling at } \\
\text { height of } \\
10 \mathrm{ft} . \text { ) }\end{array}$ & $\begin{array}{r}34 \cdot 77 \\
51 \cdot 27 \\
* 51 \cdot 50 \\
+51 \cdot 44\end{array}$ & $\begin{array}{l}9 \\
6 \\
3 \\
3\end{array}$ & $\begin{array}{l}22 \cdot 17 \\
25 \cdot 06 \\
26 \cdot 56 \\
25 \cdot 61\end{array}$ & $\begin{array}{l}22 \cdot 28 \\
24.94 \\
25 \cdot 00 \\
25 \cdot 06\end{array}$ & $\begin{array}{l}22 \cdot 39 \\
25 \cdot 22 \\
25 \cdot 28 \\
25 \cdot 39\end{array}$ & $\begin{array}{l}22 \cdot 39 \\
25 \cdot 28 \\
25 \cdot 33 \\
25 \cdot 39\end{array}$ & $\begin{array}{l}22 \cdot 39 \\
25 \cdot 17 \\
25 \cdot 28 \\
25 \cdot 39\end{array}$ & $\begin{array}{l}22.61 \\
25.78 \\
26.06 \\
26.06\end{array}$ & $\begin{array}{l}22 \cdot 50 \\
25 \cdot 39 \\
25 \cdot 61 \\
25 \cdot 67\end{array}$ & $\begin{array}{l}22 \cdot 17 \\
23 \cdot 89 \\
24 \cdot 61 \\
24 \cdot 67\end{array}$ & $\begin{array}{l}22 \cdot 50 \\
25 \cdot 11 \\
25 \cdot 28 \\
25 \cdot 33\end{array}$ \\
\hline
\end{tabular}

* Metal models full face to the wall panel.

† Metal models full back to the wall panel.

In all other experiments metal models facing along the length of the ceiling panel or profile to the wall panel.

Where the average m.r.t. from three globe thermometers is not given, the 64 in. globe was not in position. 
TABLE 3

COMPARISON OF MEAN RADIANT TEMPERATURE OBTAINED FROM STANDING AND SITTING METAL POSITION IN RELATION TO THE HEATING PANEL (Panel temp. $48 \cdot 72^{\circ} \mathrm{C}$. to $51 \cdot 67^{\circ} \mathrm{C}$.)

\begin{tabular}{|c|c|c|c|c|c|}
\hline \multirow{2}{*}{$\begin{array}{l}\text { Position of } \\
\text { Panel }\end{array}$} & \multirow{2}{*}{$\begin{array}{l}\text { Position } \\
\text { of Models } \\
\text { relative to } \\
\text { Panel }\end{array}$} & \multicolumn{4}{|c|}{$\begin{array}{l}\text { Thermopile m.r.t. minus Value } \\
\text { from Metal Models }\left({ }^{\circ} \mathrm{C} .\right)\end{array}$} \\
\hline & & $\begin{array}{c}\text { No. } \\
\text { of } \\
\text { Expts }\end{array}$ & $\begin{array}{c}\text { Standing } \\
\text { Model }\end{array}$ & $\begin{array}{c}\text { No. } \\
\text { of } \\
\text { Expts }\end{array}$ & $\begin{array}{l}\text { Sitting } \\
\text { Model }\end{array}$ \\
\hline $\begin{array}{l}\text { Ceiling at } \\
\text { height of } \\
8 \mathrm{ft} \text {. }\end{array}$ & & 2 & +0.45 & 5 & +0.90 \\
\hline $\begin{array}{l}\text { Ceiling at } \\
\text { height of } \\
10 \mathrm{ft} \text {. }\end{array}$ & & 3 & +0.50 & 2 & +0.56 \\
\hline $\begin{array}{l}\text { Wall (false ceiling } \\
\text { at height of } \\
8 \mathrm{ft} . \text { ) }\end{array}$ & $\begin{array}{l}\text { Profile } \\
\text { Full face }\end{array}$ & $\begin{array}{l}5 \\
4\end{array}$ & $\begin{array}{l}+0.56 \\
-0.22\end{array}$ & 5 & +0.22 \\
\hline $\begin{array}{l}\text { Wall (false ceiling } \\
\text { at height of } \\
10 \mathrm{ft} . \text {.) }\end{array}$ & $\begin{array}{l}\text { Profile } \\
\text { Full face } \\
\text { Back }\end{array}$ & & & $\begin{array}{l}\mathbf{5} \\
\mathbf{3} \\
\mathbf{3}\end{array}$ & $\begin{array}{l}+0.06 \\
\pm 1.28 \\
-0.28\end{array}$ \\
\hline
\end{tabular}

much higher than those for the sitting models in their other positions.

It may be concluded from Table 2 that, when the panel temperature is $48.9^{\circ} \mathrm{C}$. or over, the average m.r.t. from two globe thermometers at heights 24 and $45 \mathrm{in}$. above the floor compares more favourably with the m.r.t. obtained from the sitting models of men than does that obtained from three globes at heights 24,45 , and 64 in. At lower panel temperatures or with the panel unheated, it seems immaterial whether one, two or three globes are used. The average of the m.r.t's from the globes at 24 and 45 in. in turn gave a better comparison with the results from the models than did the results from the thermopile at $\mathbf{4 5}$ in. from the floor

The m.r.t's estimated from the sitting models were compared with the m.r.t's obtained from surface temperatures and solid angles and referred to the separate points at 24,45 , or 64 in. from the floor and with the average m.r.t. referred to two or all three of these points. The results for the combined points may be inferred from those given for single points in Table 2. The m.r.t. at 24 in. gave the best agreement with the results from the models when the panel was overhead, but with the panel on the wall the result at 24 in. was only satisfactory when the models were seated with their legs near the panel. A combination of the upper points or of all three points was more suitable with the models in the other positions relative to the wall panel.

\section{Discussion}

Yaglou (1949) stated that 'roughly comparable angle factors for a man and a globe would exist if the globe were placed about $75 \mathrm{~cm}$. $(29 \cdot 5$ in.) above the floor for a person sitting and $120 \mathrm{~cm}$. (47.2 in.) above the floor for a person standing.' Mackey (1944) concluded that a globe at 48 in. would 'give closely' the mean radiant temperature influencing the radiant heat transfer from the standing human body.

The present results support these statements for a standing man. Differences between the m.r.t's obtained from the standing metal models and those measured directly with the thermopile at $45 \mathrm{in}$. above the floor were not greater than $0.62^{\circ} \mathrm{C}$. Small differences were also found when the m.r.t. at 45 in. was obtained from surface temperatures or a globe thermometer.

The m.r.t. at 24 in. above the floor only gave good agreement with the m.r.t's obtained from the sitting metal models when the panel was overhead and the m.r.t. was estimated from surface temperatures and solid angles. When the m.r.t. was obtained from a globe thermometer reading the result at 24 in. gave no better agreement with the m.r.t. from the sitting models than did the result at 45 in., whether the panel was overhead or on the wall. The average m.r.t. from the two globes seemed to be the most satisfactory.

From the results of experiments in a radiant wind tunnel where the radiation was not uniform and the m.r.t. was as much as $33^{\circ} \mathrm{F}$. $\left(18 \cdot 4^{\circ} \mathrm{C}\right.$.) above the air temperature, Newling (1954) concluded that if the variation in m.r.t. over the space occupied by a man was less than $2.0^{\circ} \mathrm{F} .\left(1 \cdot 11^{\circ} \mathrm{C}\right.$.) a globe in one position would measure this temperature sufficiently accurately to indicate the effect of radiant heat on a man. If the variation was more than $2 \cdot 0^{\circ} \mathrm{F} .\left(1 \cdot 11^{\circ} \mathrm{C}\right.$.) measurements in more than one position would be necessary. It was then unlikely that errors of more than $2 \cdot 0^{\circ} \mathrm{F} .\left(1 \cdot 11^{\circ} \mathrm{C}\right.$.) would be made in the estimate of m.r.t. as it affected a man. The results of the present experiments are in agreement with Newling's conclusions. When the panel was on the wall, the m.r.t's from three globe thermometers differed among themselves by as much as $0.62^{\circ} \mathrm{C}$., and both the m.r.t. from the globe at 45 in. and that from the three globes agreed with that from the standing models in the profile position to within $0 \cdot 17^{\circ} \mathrm{C}$. When the models were turned to face the panel, the 45 in. globe gave the best agreement. At the higher ceiling panel temperatures the three globes differed among themselves by as much as $2.39^{\circ} \mathrm{C}$. The results in Table 2 show that the average m.r.t. from three globes gave the best comparison with the metal models.

Newling also indicated that the average m.r.t. from three globes gave better agreement with the m.r.t. from the sitting models than did the average m.r.t. from two globes at 24 and 45 in. from the 
floor. The present results have shown that at a panel temperature of over $48.9^{\circ} \mathrm{C}$, whether the panel was overhead or on the wall, the m.r.t. from the two globes gave the better indication.

The calculation of mean radiant temperature with respect to the cylinder of height $68 \mathrm{in}$. and diameter 12 in. did not give a satisfactory indication of the radiant heat load on a standing man, and it is evident that the dimensions used were not suitable. Above a height of 32 in. from the floor, the metal models had a surface area 100 sq. in. greater than the cylinder, and below that height an area 268 sq. in. less than the cylinder. Thus, with a greater area of the models exposed to overhead radiation and a greater area of the cylinder exposed to radiation from the wall panel, the m.r.t. estimated from the metal models was found to be higher than the m.r.t. referred to the cylinder with the panel overhead and lower when the panel was fixed to the wall.

Although it might be possible to calculate a suitable position for a point to be placed such that the m.r.t. obtained from surface temperatures and solid angles would give exact agreement with the m.r.t. obtained with reference to a man, the results have shown that a variety of such points would be needed to suit the panel temperature, panel position, and the orientation of the man towards the panel. Such detailed calculations would be of no practical use. Placing globe thermometers at fixed heights above the floor would seem a simpler and just as accurate a method of obtaining a good indication of the m.r.t. as it affects a man. The direct method of estimating the m.r.t. with a thermopile at $45 \mathrm{in}$. above the floor would in turn be preferable if an accurate measurement of low air speeds were not possible. At ceiling panel temperatures of $48.9^{\circ} \mathrm{C}$., a $15 \mathrm{ft}$./min. error in the estimation of air speed at $45 \mathrm{in}$. from the floor would have led to a $0.56^{\circ} \mathrm{C}$. error in the m.r.t. obtained from the globe thermometer.

\section{Conclusions}

Attention has been drawn to the fact that in nonuniform environments (1) the mean radiant temperature varies throughout the occupied space, (2) the average surface temperature is a dubious index of mean radiant temperature, (3) errors will arise in assuming that the mean radiant temperature at a point is equivalent to the mean radiant temperature as it affects a man, and (4) the heat load on a man is dependent on his orientation towards the various radiating surfaces.

While the mean of the estimates of m.r.t. from two or three globe thermometers gave good agreement with the results obtained from sitting or standing metal models of men respectively, the error in the use of one globe at $45 \mathrm{in}$. above the floor was only small. Differences between the m.r.t's obtained from the models and those measured directly with the thermopile at $45 \mathrm{in}$. above the floor were slightly greater but still did not exceed $0 \cdot 62^{\circ} \mathrm{C}$. and $1 \cdot 17^{\circ} \mathrm{C}$. for the standing and sitting models respectively. The results suggest that the 45 in. reference point should be placed in the region of the knees rather than the trunk when a man is seated with his legs near a heated panel.

Hence it seems that in indoor environments warmed by any of the more usual forms of heating installation but with no intense radiation from sharply localized sources, the simple estimation of mean radiant temperatures with a globe thermometer at $45 \mathrm{in}$. above the floor will generally give a very satisfactory indication of the heat load on a standing or sitting man.

The author wishes to express her sincere thanks to the late Dr. T. Bedford, O.B.E., for his encouragement, guidance, and helpful criticism throughout this investigation; also to Mrs. R. J. Gear for her invaluable help and her patience in the recording and analysis of instrumental data during many weeks of routine experiment.

\section{REFERENCES}

American Society of Heating and Ventilating Engineers (1945). Heating, ventilating, air conditioning guide, Vol. 23, New York: Amer. Soc. Heat. Vent. Engrs.

Barker, A. H. (1932). Proc. Instn Heat. Vent. Engrs, London (19311932), 30, 212 .

Bedford, T., and Warner, C. G. (1934). J. Hyg., Camb., 34, 458.

British Standard Code of Practice (1949). Heating and Thermal Insulation. C.P.3, Ch. VII.

Chrenko, F. A. (1953). J. Instn. Heat. Vent. Engrs, 20, 375 and 21. 145.

Dufton, A. F., and Marley, W. G. (1942). Ibid., 10, 17.

Hutchinson, F. W., and Baker, M. (1951). Heat. Pip. Air Condit., 23 (Journal Sect.), June, p. 108.

Mackey, C. O. (1944). Cornell Univ. Eng. Exp. Station Bull., 33. New York: Cornell Univ.

Macpherson, R. K. (1960). Spec. Rep. Ser. med. Res. Coun., Lond., No. 298.

Newling, P. S. B. (1954). The measurement of mean radiant temperature and the determination of the amount of radiant heat gained by $a$ and the determination of the amount of radiant heat gained
man. Med. Res. Coun., Lond., R.N.P. Rep. No. 54/784.

Raber, B. F., and Hutchinson, F. W. (1947). Panel Heating and Cooling Analysis. Wiley, New York.

Vernon, H. M., and Manley, J. J. (1926). Spec. Rep. Ser. med. Res. Coun., Lond., No. 100, Pt. 1.

Yaglou, C. P. (1949). Indices of comfort. In Physiology of Heat Regulation and the Science of Clothing by L. H. Newburgh, pp. 277-287. Philadelphia: Saunders. 